Article

\title{
Assessment of Visual Values as a Tool Supporting the Design Decisions of the Cultural Park Protection Plan. The Case of Kazimierz and Stradom in Kraków
}

\author{
Urszula Forczek-Brataniec (10) \\ Chair of Landscape Architecture, Faculty of Architecture, Cracow University of Technology (CUT), \\ Warszawska 24, 31-155 Kraków, Poland; uforczek-brataniec@pk.edu.pl
}

check for

updates

Citation: Forczek-Brataniec, U. Assessment of Visual Values as a Tool Supporting the Design Decisions of the Cultural Park Protection Plan. The Case of Kazimierz and Stradom in Kraków. Sustainability 2021, 13, 6990. https://doi.org/10.3390/ su13136990

Academic Editor: Carmela Cucuzzella

Received: 30 April 2021

Accepted: 17 June 2021

Published: 22 June 2021

Publisher's Note: MDPI stays neutral with regard to jurisdictional claims in published maps and institutional affiliations.

Copyright: (C) 2021 by the author. Licensee MDPI, Basel, Switzerland. This article is an open access article distributed under the terms and conditions of the Creative Commons Attribution (CC BY) license (https:/ / creativecommons.org/licenses/by/ $4.0 /)$.

\begin{abstract}
Krakow is a city of high landscape values, which has found confirmation in the entry onto the UNESCO heritage list. Its cultural landscape requires protection and clarification within the context of intensive tourist use and a rapid pace of urban spatial development. For preservation protection and restoration of landscape values, the city authorities undertook work on the creation of a Cultural Park in the Stradom and Kazimierz districts, providing a comprehensive, sustainable, and multidisciplinary approach to natural, cultural and visual values of the urban structure. The article presents the application of the method of research on visual values in order to protect individual scenic resources of the historical urban structure. It is one of the analytical studies of a comprehensive protection plan project. This project defines the scope, framework and methods of development and management of a Cultural Park. The task of the visual analysis was to identify, characterize and evaluate the visual resources. It created a visual framework for further development of the historical district while preserving its local spatial identity. The studies resulted in a division into zones according to their nature and intensity of activities as well as outlining protection zones and intervention zones adjusted to individual characteristics of those places. An original method combining achievements of the method of landscape and visual assessment (LVIA) as well as achievements of the Krakow School of Landscape Architecture (KSLA) in terms of cultural landscape assessment was used for the research. The applied method provided guidelines to support sustainable project decisions regarding further development of the district for the preservation of local spatial identity. Its universal character creates possibilities for its application into the plans of other Krakow districts and is intended to be applicable to both urban and rural structures.
\end{abstract}

Keywords: heritage visual value; urban heritage protection; urban spatial structure; visual analysis; visual landscape

\section{Introduction}

Currently, historical and old city centres and districts remain influenced by a high number of factors impacting their space. Such issues as historical substance, intensive use and the necessity of adjusting to contemporary needs require a proper approach to design and management. At the same time, urban development outside the historical centre might impact their shape through borrowed views. In this context, townscape calls for multithreaded protection which allows for preserving the highest values while adjusting to the changing conditions of their use and needs related to the functioning of a modern city.

These problems are compounded in cities of significant historical value. They are mentioned and discussed in declarations and recommendations of UNESCO, whose approach to the city landscape is evolving [1]. On the basis of this evolving approach to UNESCO heritage in the context of Polish legal conditions, as early as 2003, a formula was created for the protection of the cultural landscape in the form of the Cultural Park. It assured a comprehensive approach to historic areas that requires taking into account natural, cultural and visual aspects. 
A Cultural Park is a project that facilitates comprehensive protection of city landscape [2], a legally established form of integrated and area protection, covering a wide context. It is legally regulated by the Act on the Protection and Care of Monuments of 3 July 2003 [3].

Protection objectives are clearly defined in Art.16 point 1 of this Act that states the following: the city council after having been advised by the provincial conservation officer, based on the Law, can create a Cultural Park for protection of cultural landscape and preservation of distinguished landscape areas containing immovable historical buildings characteristic for local building and settlement tradition. This Cultural Park is to serve for integrated protection of landscape urban, architectural, and natural values of the place while taking into account the needs for sustainable development and preservation of the character of functioning residential district while maintaining good life conditions and cultural specificity [4].

The formula of a Cultural Park imposes the obligation to prepare a protection plan for its area and then to prepare a local spatial development plan for the area of a Cultural Park, which becomes an act of local law. The protection plan serves the realization of the protection objectives of the Cultural Park. The protection plan is a flexible formula that allows the plan scope to be adapted to the specificity of its resources. The plan includes the identification of the features of the cultural landscape, natural and social conditions, and the analysis of viewing conditions. An in-depth analysis of these issues leads to synthesis and further steps to develop and implement a Cultural Park protection plan.

This article presents one of the threads of an analysis which is a study of visual values. It presents the application of the research on visual resources on the basis of which the scenic values were identified and characterized. The purpose of the study was to outline a spatial framework of the development of cultural and natural substance thus allowing for preservation, protection or restoration of its most precious exposure. The visual values have become one of the components of the integrated protection of the cultural landscape.

The basis for the studies constituted guidelines on the preparation of protection plans, in which the survey of scenic resources is, apart from studies related to cultural and natural resources, an integral part of the Cultural Park protection plan project.

In 2000 landscape was defined as an area, as perceived by people, whose character is the result of the action and interaction of natural and/or human factors by the European Landscape Convention (ELC) [5]. This definition highlights the perceptive aspect which has become equivalent with natural and cultural resources while giving it its rightful place in managing landscape resources. The idea of a Cultural Park follows this approach to landscape. This holistic form allows us to develop a protection plan for the preservation of the most precious cultural and natural values in the process of further spatial planning. This form incorporates the idea of balanced integrated protection while taking into account cultural, natural and landscape and visual aspects. It uses the experience of the system of planning of protected areas, which has proved to be very successful [6,7].

\section{State of the Art}

The issue of the city view has a rich history of studies starting from works by $\mathrm{K}$. Lynch [8] who discovered and endorsed visual perception of the city in planning, and such authors like G. Cullen [9] or J. A. Jackle [10] as well as S. Bell [11] who limited landscape perception to the alphabet of spatial forms. This line is continued in contemporary studies where special attention is paid to spatial analyses of Warsaw within the context of the language of patterns [10], an analysis of the curve of impressions evoked by contemporary urban space [12] which refers to the method by T. Wejchert $[13,14]$. The issues of identifying and assessing the city's views are developed by English Heritage, and the publication "Seeing the history on the View. A method of assessing heritage significance within Views" presents an approach that can be applied to any view that is significant in terms of its heritage values [15]. 
An important modern aspect of visual studies is the influence of the visual quality of landscape on the quality of life [16]. They are related to the approach to landscape initiated by Humbolt-landscape as a living environment [17]. Currently, humanistic geography, sociology and humanistic archeology continue this research by studying the relationships between man and the inhabited environment. The issues of the relationship between humans and space raised by Yi-Fu Tuana [18] are explored and developed in relation to the role of society in shaping space [19]. An important issue is also the question of the relationship between historical heritage and the way it is understood and perceived. In this respect, urban geography developed by David Lowenthal and his followers draws our attention to contemporary processes and problems expressed in the form of space $[20,21]$ and the relationship between its community and the past [22].

Historical city centers struggle with numerous problems resulting from the condensation of sociological and spatial issues [7]. One of the most important dilemmas is the intensive development of city outskirts with a simultaneous decline in the number of permanent residents in historical centers [23]. One of the manifestations of this process is "gentrification", loss of inhabitants and, consequently, loss of the identity of the place [2]. When the focus on profit and tourist exploitation is added to this, the situation gives rise to a high number of negative effects manifested in the transformation of space. As a result, they undergo processes that pose a threat to both tangible and intangible values [2].

The effects of extensive exploitation take on different forms. These are both attempts to increase real property development intensity and introducing spatial objects that deform the urban structure [24] and accumulation of secondary elements related to use and deforming the city space defined as visual pollution [25].

In this context, UNESCO's declarations mean great opportunities in implementing protection measures based on increasing awareness of the local community and participation of residents in protection $[2,22,26]$. In the face of changes, a view can constitute a permanent base for creating and maintaining a bond with space. Particularly in the face of the changing reality, Kobayashi [27] demonstrated the significance of cultural forms in the landscape while Cosgrowe emphasized the importance of visual perception both in the creation and interpretation of landscapes [28]. Technical sciences and architectural and landscape approaches to shaping space come out against the humanities. As one of the elements of an integrated approach to heritage, they deal with the protection and shaping of a form that constitutes a cultural resource in the form of a place and the surrounding space. Their role is emphasized by Ti Fu Tuan, pointing to the need for a "creative and artistic" approach to space, which eludes "computational-statistical" methods [18]. The processes taking place in historic urban spaces are reflected in the evolution of documents related to the UNESCO heritage. Particularly noteworthy is the 1962 Declaration on the Beauty and Character of Landscapes and Places [29], the ICOMOS Xi'an declaration of 2005 emphasizing the importance of the building's surroundings [30], including visual interaction with the surrounding landscape. Contemporary threats and conservation objectives are clearly defined in the UNESCO Recommendations of 2011 [2]. They emphasize the definition of cultural values, including visual values, the need for integrated protection and the threats resulting from the rapid development and fragmentation of cities. On the other hand, the issue of the protection of the wide landscape as a component perceived of natural and cultural origins was extended in the ICOMOS Florence Declaration of 2014 [31], drawing attention to the need for creating a sustainable landscape of contemporary cities. Visual values play an important role in the definitions of subsequent UNESCO and ICOMOS documents while the existence of a protection zone in the form of a buffer zone plays not only a protective but also an educational role, highlighting the importance of the context as well as the visual connections between the site and space. The need to study the viewing context of cultural heritage meets the methods developed in the context of the protection of the open landscape. 
They constitute the contemporary trend developed within the method which referred to the assumptions of the British Landscape Character Assessment (LCA) and the Landscape and Visual Impact Assessments (LVIA) conducted for the purposes of environmental impact assessments (EIA). They originate from visual quality studies and new investments impacting open landscape [6,32]. However, the main methodical scheme finds application in various landscape visual studies, which Gobster, Ribe and Palmer stress in an overview for application of this method [33]. Furthermore, the authors of the latest issue of the instruction for defining visual impact on landscape Guidelines for Landscape and Visual Impact Assessment (GLVIA) clearly indicate its significant contribution into studies of urban space while articulating the need for its application and the need to conduct new studies that would integrate the achievements in this respect [34]. The implementation of these methods has many uses [33].

One of them is an analysis of the impact of new investments on the urban structure. Due to the nature of the studies and application of modern digital tools, they impact both significant development of analysis methods and updating the guidelines adjusted to new possibilities. What deserves particular attention here is the development of the methods for studying viewsheds $[35,36]$, the development of guidelines for regulating visualisations [37] as well as the development of the methods related to the use of digital analytical tools for studying urban and suburban zones [38,39].

At the same time, it applies the methods related to protected areas. The concept of monitoring points applied here is based on the effectiveness of the method called Red Flag Points (RFP) by R.B. Litton [40] and Palmer's [41] method of Key Observation Points (KOP) developed based on the previous method. On this basis, a network of monitoring points of urban space was created.

The Krakow School of Landscape Architecture (KSLA) reaches for early methods of landscape analysis. While it is based on analyses of architectural forms and their exposures [42], it also built its own approach which was later developed and improved through new experiences and challenges [43]. Their synthesis constitutes a comprehensive method by Professor Bogdanowski based on the comprehensive approach to landscape issues [44]. The starting point is the landscape form which constitutes the basis for landscape division into units or architectural and landscape enclosures depending on the analysis scale. This division allows for creating landscape separations which are later assessed and then zoned out. Toned down urban enclosures of WAK (architectural and landscape enclosures) at the outset define the spatial form as the framework for further studies in terms of the analysis and assessment of cultural resources [45]. The enclosure method was created to analyse cultural landscapes with clear-cut historical values. It focuses its attention on substance values and composition values. This approach became the focus for the development of this form of landscape cultural protection, i.e., the Cultural Park [46]. While it is supplemented with natural threads, it represents an integrated approach to urban space thus becoming the basis for planning in the spirit of sustained development. Here, the sustainable aspect refers to landscape management both with reference to its substance and the form perceived, which, as a result, leads to recognizing the view as a resource that is the subject of proper sustained management [47].

Landscape visual values, which constitute the value of a given place, require a specific approach so that this value would not be degraded. This approach will allow their preservation in the course of further development and use. In this case, the visual analysis takes into account individual landscape resources, including historical resources and spatial dependencies so as to create a framework for further development while being aware of their values. It aims at preserving the most precious views and spatial relations as well as finding space for activities responding to the needs of a modern city.

The approach that combines the achievements of visual assessment [34] and the Krakow School of Landscape Architecture (KSLA) allows for using and integrating achievements and experiences in this respect, which proved especially valuable and beneficial in historical urban space. 
Expert studies related to visual aspects are conducted in a number of scientific centres. Most of them concern selective issues related to the location of particular objects in urban space [48] while focusing on their impact on the composition and analysing the possibilities for further development [49]. Special attention should be devoted to the studies of possibilities of the location of high-rise buildings [50] in the context of city panoramas as well as extensive research of visual absorbency [51]. At the same time, there are studies of historical substance and its perception [52].

The method presented in the article brings together the issues of valuation of cultural landscape specific to the Krakow School of Landscape Architecture with studies of spatial dependencies conducted with the use of contemporary methods in the field of visual assessment [34]. It refers to spatial substance and its exposure. While based on the method of division into landscape enclosures [43,44] it indicates their visual characteristics due to active and passive exposure [6]. In terms of active exposure, it determines the content of visual points and visual paths in space. In terms of passive exposure, it characterises urban structure with reference to its historical quality and composition. This approach allows us to bring out the individual spatial character of every enclosure as well as assess its visual value and conduct proper zoning out due to landscape protection. In the case of Stradom and Kazimierz, more significant criteria were added, namely the view pollution index. This criterion is related to the build-up of elements disturbing the perception of space as a result of negligence and lack of regulations in the use of space. Defining this factor was essential for the classification of interventions in particular zones. Enriching the KSLA method with visual assessment tools allowed for developing an individual method that makes it possible to identify visual values, their characteristics and assessment in order to then separate zones with specific guidelines. The study conducted in this way solidified the need to protect exposure and constituted the basis for the application of the guidelines in further planning and management of space.

\section{Materials and Methods}

The study area is located in Krakow, an early Medieval city located in southern Poland. The urban structure of the city is a layered system. It is composed of districts of different origins and times of creation [53]. The study areas of Stradom and Kazimierz are Medieval districts with preserved urban layout and substance in the form of historical objects. These include sacral buildings dating back to the 14th century, public buildings as well as housing. In the 19th century, the Medieval city walls were torn down while the old moats, as well as the Vistula riverbed, were filled up due to sanitary reasons and because of merging adjacent districts in the city [54]. It was then that new streets were marked out and the urban tissue was replenished. The Second World War affected the district greatly due to mass resettlements of the Jewish community from Kazimierz to the nearby ghetto. After the Second World War, this area gradually degraded, and underwent reconstruction and reinvestment. The significant redevelopment was connected with the winding-up of 19th-century industrial plants and replenishing real property development. As a result of many phases of development, the subject study area presents a complex spatial structure of different origins and different states of preservation [55]. It stands out in terms of picturesqueness and boasts an intriguing compositional arrangement built on valuable visual connections. At the same time, there are areas that are significantly polluted due to intensive tourist traffic and many years of negligence in terms of clearing out public space. In recent years, Krakow has been visited by an average of almost 10 million tourists a year [56]. Because of the value of historical substance, spatial diversity and many years of layered neglect, the city authorities decided to start the procedure of encompassing the area with a holistic protection plan in the form of a Cultural Park. On 12 June 2019, the Krakow City Council adopted a resolution on the announcement of the commencement of work on the creation of a Cultural Park Kazimierz and Stradom. In 2020, work began on the protection plan project, in 2021 project was completed. 
One of the elements for developing this protection plan project was a visual analysis. Visual analysis was to identify and assess visual values. This then leads to formulating guidelines for preservation protection and restoration of visual values.

The method of visual landscape studies applied for the needs of the plan for Cultural Park protection combines the achievements of visual assessment and the Krakow School of Landscape Architecture. From visual assessment, it takes the procedure and it uses the advanced tools for visual analyses from the KSLA method it borrows a specific approach that is typical for protected landscapes as well as the issues of the visual analysis [46].

It consists of identifying and characterizing the resource, assessment of visual values and formulating guidelines for further stages of project works.

Identifying the resource occurs on the basis of desk study and field study [57]. This stage of the project relies first and foremost on obtaining the information necessary for further analyses. The preliminary works included analyses of archive materials, developing a model for defining visual relations of spatial elements as well as an initial analysis of the spatial structure. Since the study is a part of a multidisciplinary report, it is based on one common matrix. The basis of the study was a division into architectural and landscape enclosure [58] which all of the studies followed. The starting point was an enclosure while enclosures of similar characteristic features and origin constituted a group of enclosures.

Identification of visual resources of enclosures was based on the KSLA division into active and passive exposure [42,59]. Active exposure is related to landscape observation whereas passive exposure means exposing it in the form of frames, views, and panoramas. This distinction made it possible to distinguish functional dependencies of the exposure on the seen views. Active exposure elements comprise points, visual paths, visual surfaces and visual axes. Passive exposure elements comprise the following: dominants, subdominants, accents, foreground and background. The specifics of active exposure results from the location of the point, visual paths, etc., and it is connected to its management. Passive exposure is a view while a panorama is an image whose unveiling is dependant on the spatial structure and substance it is built on. Active exposure is also called view availability. Passive exposure is also called view substantion. Both exposure categories are closely related to each other and interdependent. However, their specification decides on a different approach.

Due to the nature of Stradom and Kazimierz, an additional category of identification was applied in the form of the degree of view pollution. Investment layering, lack of renovation activity, lack of successive cleaning activity with reference to public transport, advertisement and information space created a surface of clutter that calls for immediate intervention in terms of cleaning. Defining the degree of pollution and its identification was the source of significant data to define further activity for improving the visual values of the analysed object (Figure 1). 


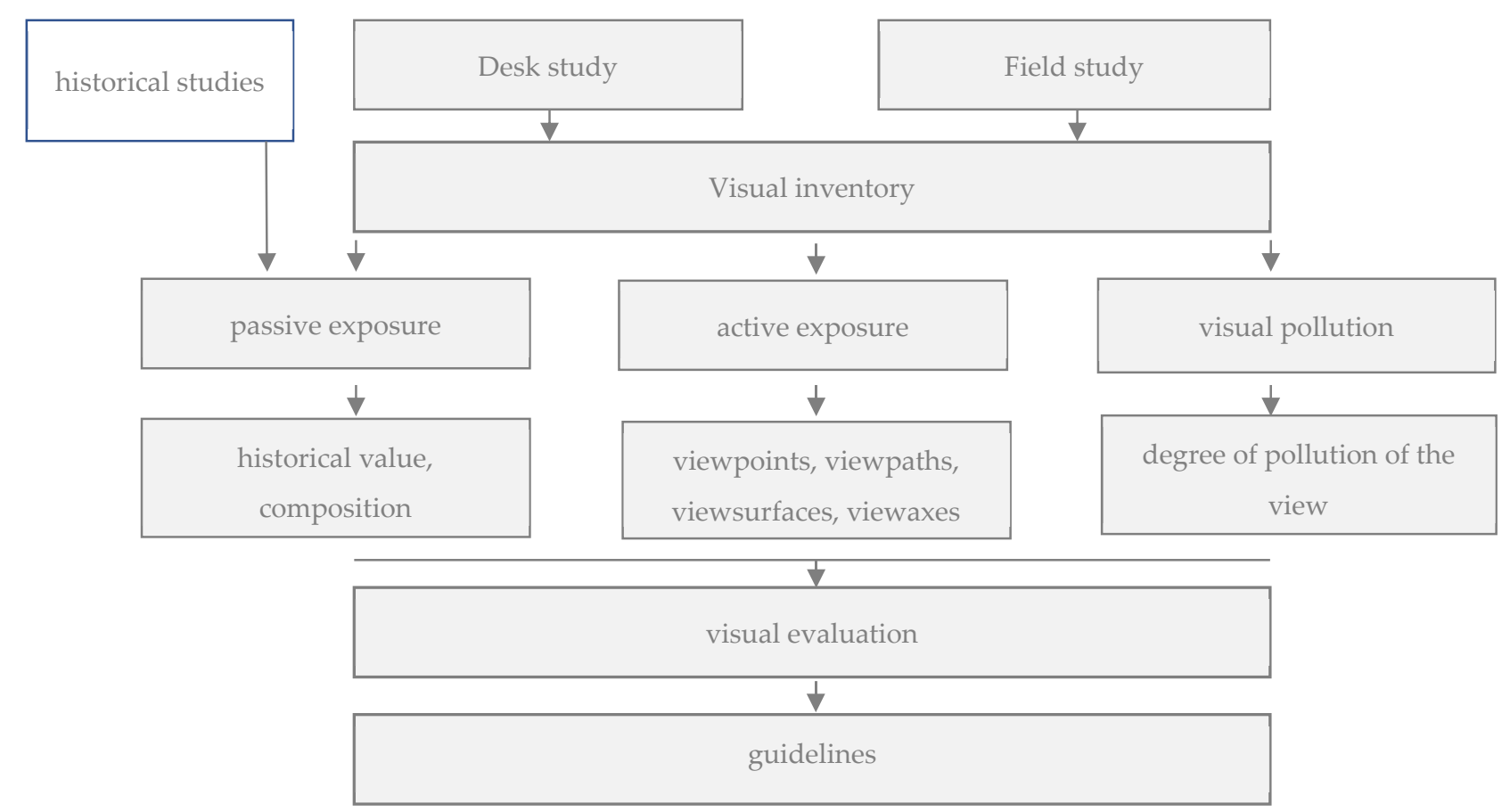

Figure 1. Visual analysis method diagram.

\section{Results}

\subsection{Visual Inventory}

Identification of the visual resource constitutes the basis work for assessment and then zoning. It comprises desk study and field study. Desk study means, first of all, collecting starting materials on both historical and spatial issues. Since the team responsible for the development of the Cultural Park protection plan comprises representatives of various fields, detailed historical research was conducted by historians and art historians. They provided selected materials required for the identification of visual resources. These included archival materials, historical pictures, maps as well as all types of source materials. Moreover, a team of historians made an in-depth analysis of the stages of the city's development and its transformations. The visual analysis was based on these findings. On the basis of iconographic materials, the selection was made and historical pictures were compared to the current state. This constituted the basis for selecting visual points and their hierarchy which was at a later stage verified during field study (Figure 2).

A desk study was also carried out in the field of spatial relations analyses. The maps were analyzed and preliminary visibility charts were prepared as well as crosscut sections for defining fundamental visual connections. Items significant for urban composition were pre-defined similarly to the visual ranges of the dominant objects. An important element of desk study was an analysis of visual ranges (Figure 3). Placing them made it possible to identify the areas where views intensified onto the key spatial objects.

A field study means, first and foremost, the verification of data and keeping inventory. The identification process takes place alongside the comparison of historical pictures to the real state. Another process is the verification of view ranges and the photographic inventory of views where view ranges are overlapping. Hierarchy of views also takes place.

As a result of combining desk and field studies, enclosure characterisation is defined in terms of active and passive exposure. 

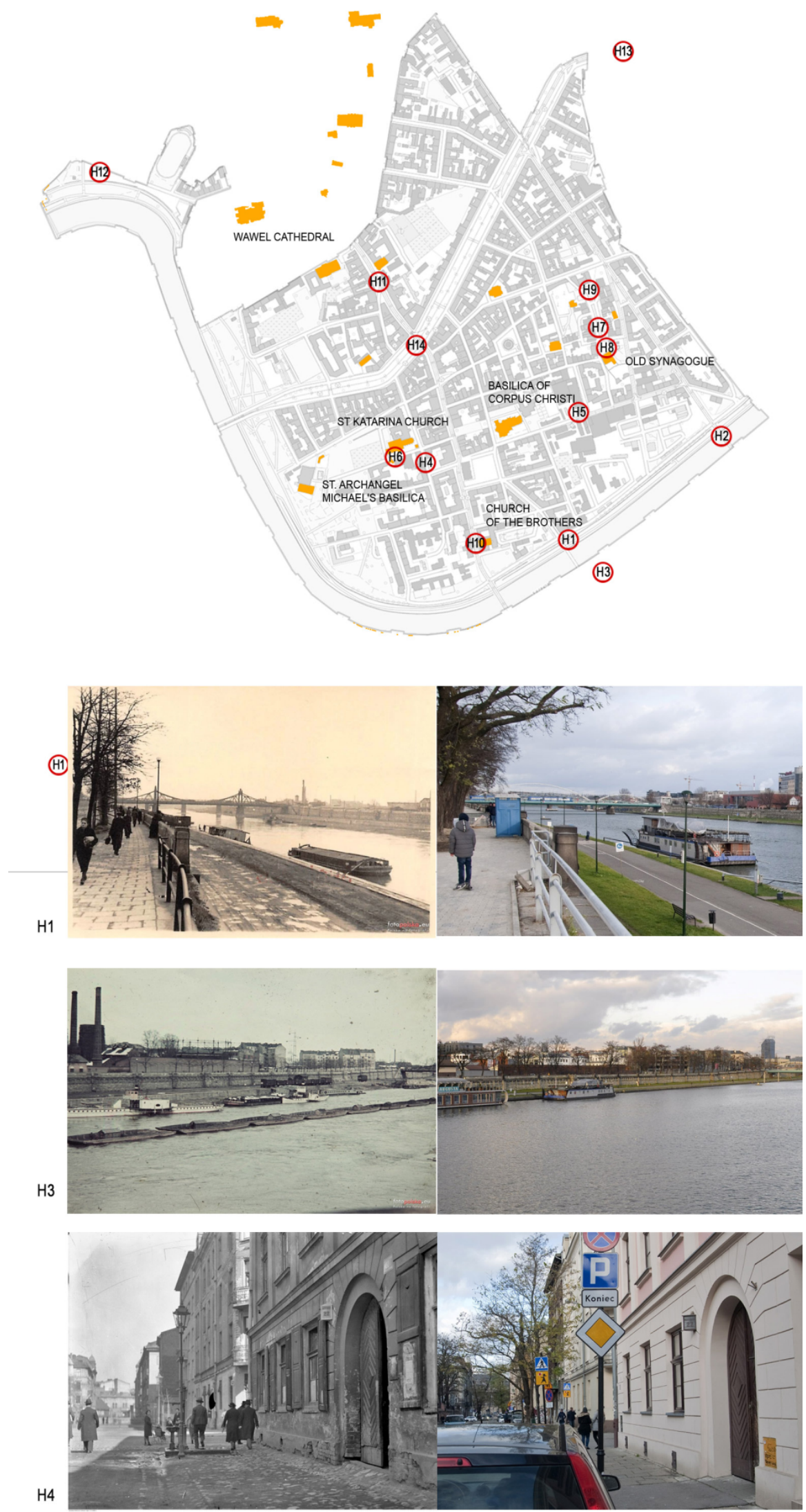

Figure 2. Comparison of archival and contemporary pictures as a basis for creating hierarchy of visual points. 

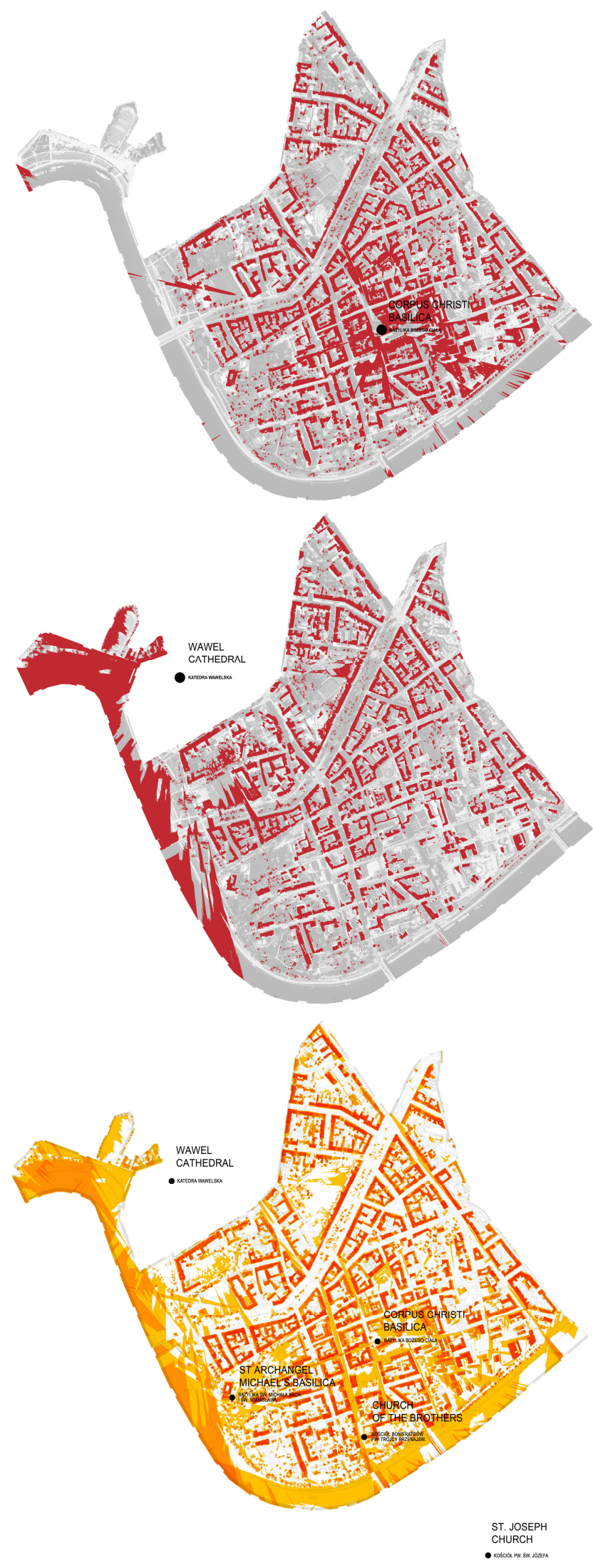

Figure 3. Visibility maps for dominants and subdominants of Stradom and Kazimierz. From the top: an exemplary viewshed of the Corpus Christi Basilica; viewshed of the Wawel Cathedral: the bottom figure presents a compilation of the viewsheds of all the landscape dominants. 


\subsubsection{Active Exposure}

Active exposure of an enclosure is defined by exposure elements in the form of points, visual paths, surfaces, and visual axes. Elements of active exposure are at the same time characterized by their significance. Key, characteristic and supplementary elements are distinguished. Another step involves the selection of monitoring points for particular enclosure groups.

The basis for defining elements of active exposure is field study supported by desk study. In this case, methodology achievements in the field of visual assessment are used [34]. In order to identify the points of the widest range, analyses of visibility are applied. An analysis of views from the highest and most attractive objects of the urban layout defined as dominants and subdominants makes it possible to locate the places from which they are seen as a single one or a group. Their exposure defines the spatial shape of the views as well as their attractiveness $[60,61]$. For studying this issue, the degree of visibility index is used [62]. Overlaying viewsheds becomes the basis for defining the number of visible dominants from a given place. These data take on the form of a degree of visibility map (Figure 4). The higher the degree, the more dominants are visible from a given place. The data obtained in digital analyses are verified in the field. As a result, combining the desk study and field study helps to define and create a hierarchy of elements of active exposure.
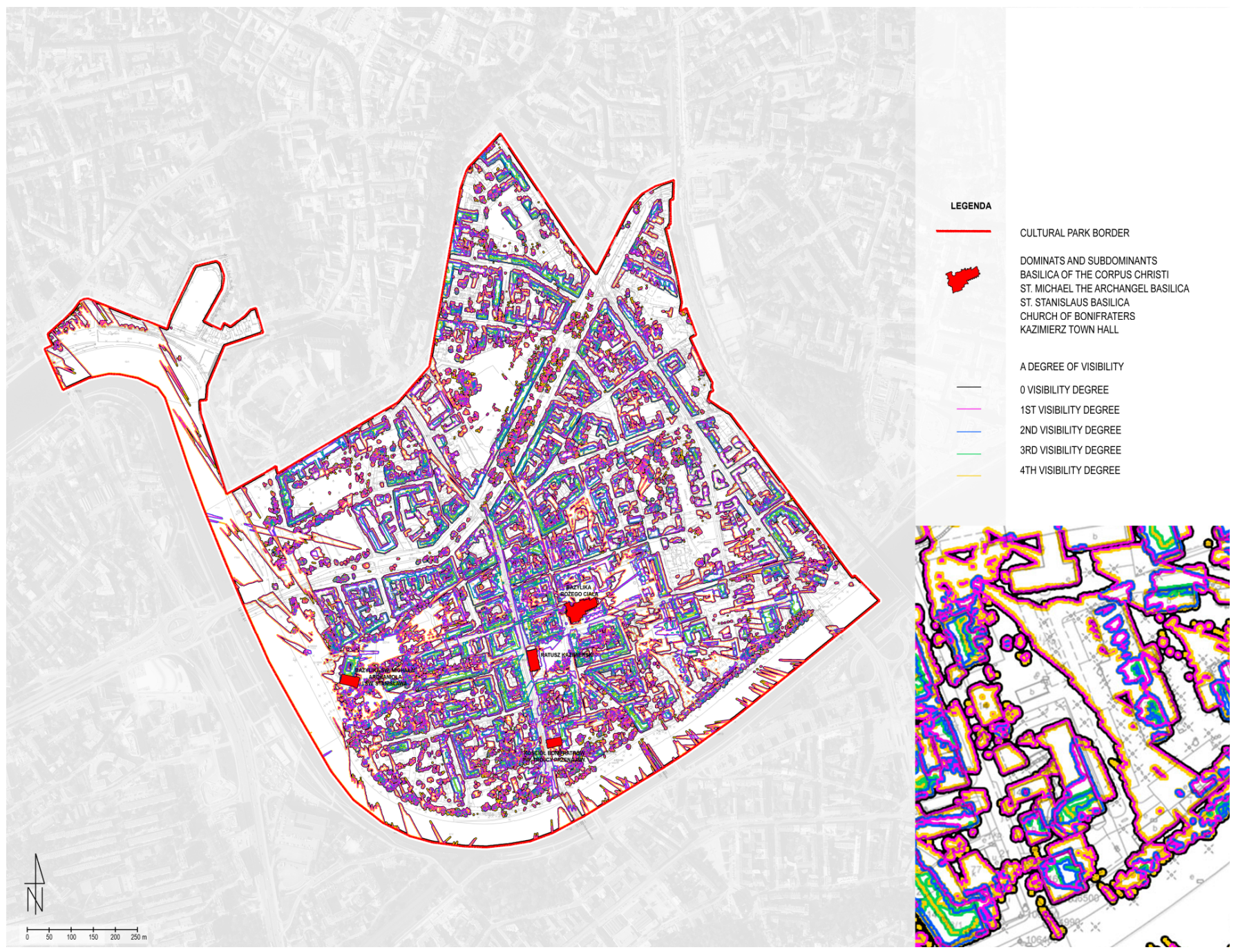

Figure 4. A degree of visibility map. 
On the basis of studies of active exposure, the final version of the map of elements of active exposure is prepared (Figure 5). It is supplemented with panoramas of key characteristics and supplementary points. Additionally, a comparison table is prepared (Table 1). It contains elements of active exposure for every enclosure that then becomes the basis of its valuation in this respect, in terms of the content of places from which the views are most attractive.

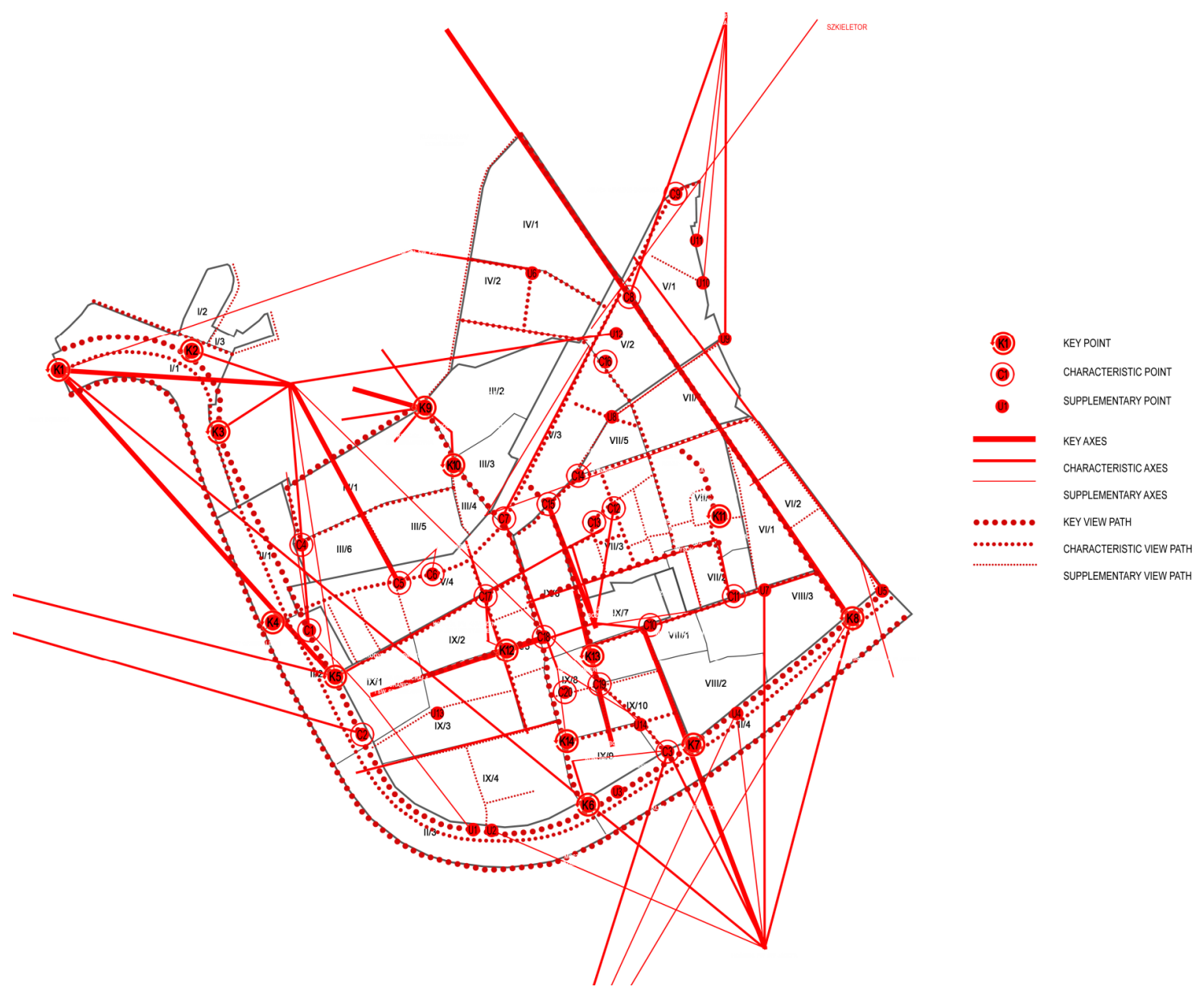

Figure 5. Map of active exposure.

Table 1. Comparison of elements of active exposure in particular enclosures (WAK). Letter symbols: K—key element; $\mathrm{C}$-characteristic element; S-supplementary element. The table presents the number of active exhibition elements present in individual enclosures.

\begin{tabular}{|c|c|c|c|c|c|c|c|c|c|c|c|c|c|}
\hline \multirow{2}{*}{ ZWAK } & \multirow{2}{*}{ Wak } & \multicolumn{3}{|c|}{ Viewpoints } & \multicolumn{3}{|c|}{ Viewpaths } & \multicolumn{3}{|c|}{ Viewaxis } & \multicolumn{3}{|c|}{ Viewsurfaces } \\
\hline & & $\mathbf{K}$ & $\mathrm{C}$ & $S$ & $\mathbf{K}$ & $\mathrm{C}$ & $\mathrm{S}$ & $\mathbf{K}$ & $\mathrm{C}$ & $S$ & $\mathbf{K}$ & $\mathrm{C}$ & $S$ \\
\hline $\mathrm{I} / 1$ & Wistula band & 3 & & & 2 & 2 & & 2 & 3 & 1 & 1 & & \\
\hline $\mathrm{I} / 2$ & Na groblach sqare & & & & & & & & & & & & \\
\hline $\mathrm{I} / 3$ & Podzamcze & & & & & & 1 & & & & 1 & & \\
\hline $\mathrm{II} / 1$ & Rybaki & 1 & & & 2 & 1 & & & & & 1 & & \\
\hline $\mathrm{II} / 2$ & Bulwar Inflancki pn & 1 & 2 & & 2 & 1 & & 1 & 3 & 2 & 1 & & \\
\hline $\mathrm{II} / 3$ & Bulwar Inflancki pd & & & 2 & 2 & 1 & & & & 2 & 1 & & \\
\hline $\mathrm{I} / 4$ & Bulwar Kurlandzki & 3 & 1 & 3 & 2 & 1 & & 1 & 4 & 3 & 1 & & \\
\hline
\end{tabular}


Table 1. Cont.

\begin{tabular}{|c|c|c|c|c|c|c|c|c|c|c|c|c|c|}
\hline \multirow{2}{*}{ ZWAK } & \multirow{2}{*}{ Wak } & \multicolumn{3}{|c|}{ Viewpoints } & \multicolumn{3}{|c|}{ Viewpaths } & \multicolumn{3}{|c|}{ Viewaxis } & \multicolumn{3}{|c|}{ Viewsurfaces } \\
\hline & & $\mathbf{K}$ & $\mathrm{C}$ & $S$ & $\mathbf{K}$ & $\mathrm{C}$ & $S$ & $\mathbf{K}$ & $\mathrm{C}$ & $S$ & $\mathbf{K}$ & $\mathrm{C}$ & $\mathrm{S}$ \\
\hline III.1 & Bernardyni & 1 & & & & 2 & 1 & 1 & 6 & & & & \\
\hline III. 2 & Misjonarze & & & & 1 & & & & & & & & \\
\hline III.3 & Bożogrobcy & & & & 1 & & & & & & & & \\
\hline III.4 & Piekiełko & 1 & & & & & & & 1 & & & & \\
\hline III. 5 & Koletek & & & & & & 1 & & & & & & \\
\hline III.6 & Nadwiślan & & 1 & & & & 1 & & & & & & \\
\hline IV.1 & Starowiślna & & & 1 & & 1 & 1 & & 1 & & & & \\
\hline IV.2 & Św. Sebastiana & & & & & 2 & 1 & & & & & & \\
\hline V.1 & Wrzesińska & & 1 & 3 & & 1 & 1 & & 1 & 2 & & & \\
\hline V.2 & Berka joselewicza & & 2 & 1 & 1 & 2 & & & 2 & & & & \\
\hline V.3 & Dietla pn & & 1 & & 1 & 3 & & & 1 & & & & \\
\hline V.4 & Dietla pd & & 2 & & 1 & 2 & 3 & 1 & 1 & 2 & & & \\
\hline VI.1 & Dajwór & & & & 1 & & 1 & & & & 1 & & \\
\hline VI.2 & Halicka & & & & & 1 & 4 & & & 2 & & & \\
\hline VII.1 & Szeroka & 1 & & & 1 & 1 & 3 & & & & 1 & & \\
\hline VII.2 & Bawół & & 1 & & 1 & 1 & 1 & & & & & & \\
\hline VII.3 & Plac nowy & & 3 & & 2 & 3 & 4 & & 1 & & 1 & & \\
\hline VII.4 & Miodowa & & & & 1 & 2 & 1 & & & & & & \\
\hline VII.5 & Brzozowa & & 1 & 1 & & 1 & 1 & & & 1 & & & \\
\hline VIII.1 & Zajezdnia & & 1 & & & 1 & 1 & & & & & & \\
\hline VIII.2 & Gazownia & & & & 1 & & 1 & & & & & & \\
\hline VIII.3 & Elektrownia & & & & 1 & & & & 1 & & & & \\
\hline IX.1 & Skałka & & & & 1 & 1 & & & & & & & \\
\hline IX.2 & Augustianie & & & & 1 & 2 & & & & & & & \\
\hline IX.3 & Piekarska & & & 1 & & & 1 & & 1 & 1 & & & \\
\hline IX.4 & Skawińska & & & & & & 3 & & & & & & \\
\hline IX.5 & Krakowska zach. & 1 & 1 & & 2 & 2 & 2 & & & 1 & & & \\
\hline IX.6 & Krakowska wsch. & & 1 & & 3 & 1 & & 3 & & & & & \\
\hline IX.7 & Boże ciało & & & & 1 & 1 & & & & & & & \\
\hline IX.8 & Wolnica & 1 & 2 & & 2 & 1 & 1 & 2 & & & 1 & & \\
\hline IX.9 & Bonifratrzy & 1 & & & 1 & 1 & & & & & & & \\
\hline IX.10 & Mostowa & & & 1 & & & & & 3 & 1 & & & \\
\hline
\end{tabular}

The graphic presentation in the form of a map reveals a specific spatial composition of the analysed area as a synthesis. In the diagram of the visual axes pattern of Kazimierz and Stradom, fundamental features of visual connections can be observed. These characteristics demonstrate the individual nature of the analysed space. The graphics are in the form of a diagram. It exposes the compositional and spatial specifics of the townscape and reflects its internal arrangement as well as the degree of visual connection with other districts in the city (Figure 6).

\subsubsection{Passive Exposure}

The nature of passive exposure is defined by two factors, namely the quality of the substance which builds the space as well as the composition which creates the mutual pattern of particular elements.

The quality of substance was defined on the basis of works by a team of historians (Table 2). Every enclosure gained historical value. The approved criteria were based on the state of preservation, the clarity of the pattern as well as the diversity of the pattern. 


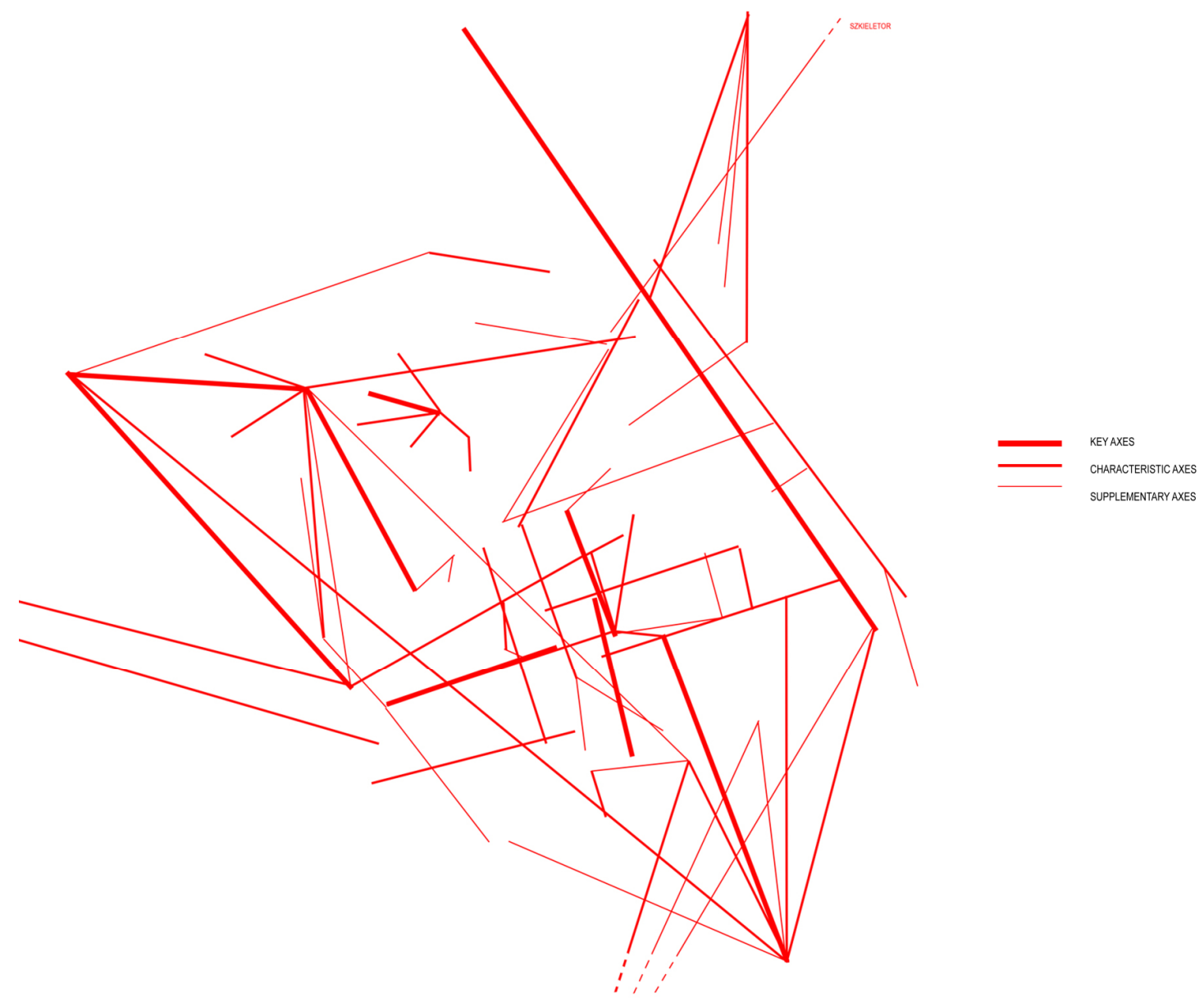

Figure 6. Map of visual axes-diagram of the compositional and spatial specifics of townscape.

Table 2. Historical values of the landscape substance (example ZWAK I and II).

\begin{tabular}{ccc}
\hline ZWAK & WAK & Historical Values \\
\hline I/1 & Vistula band & Low \\
I/2 & Na Groblach Square & Medium \\
I/3 & Podzamcze & Medium \\
II 1 & Rybaki & High \\
II $/ 2$ & Bulwar Inflancki N & High \\
II/3 & Bulwar Inflancki S & High \\
II $/ 4$ & Bulwar Kurlandzki & High \\
\hline
\end{tabular}

The compositional nature was defined on the basis of visual features of the enclosure. The following view features were taken into account: depth, distance, width, multiplanning, and presence of borrowed views. Comparing compositional features of particular enclosures is presented in the table (Table 3). The material in the form of panoramas illustrates the occurrence of features characteristic for the composition (Figure 7). The table specifies the presence of particular features of the view while graduating them in three degrees: high, medium, and low. The presence of these features becomes the basis for the assessment of passive exposure. 
Table 3. Composition characteristics of enclosures were made on the basis of the occurrence of specific visual features of the enclosure, such as: 1. Distance, 2. View depth, 3. Width, 4. Multiplanning, 5. Presence of borrowed views (example ZWAK I and II). Letter symbols refer to the significance of these features: $\mathrm{H}-$ high, $\mathrm{M}$-medium, L-low.

\begin{tabular}{|c|c|c|c|c|c|c|}
\hline \multirow{2}{*}{ ZWAK } & \multirow{2}{*}{ WAK } & \multicolumn{5}{|c|}{ Composition Elements } \\
\hline & & 1 & 2 & 3 & 4 & 5 \\
\hline $\mathrm{I} / 1$ & Vistula band & $\mathrm{H}$ & $\mathrm{H}$ & $\mathrm{H}$ & $\mathrm{H}$ & $\mathrm{H}$ \\
\hline $\mathrm{I} / 2$ & Na Groblach Square & $\mathrm{L}$ & $\mathrm{L}$ & $\mathrm{L}$ & $\mathrm{L}$ & $\mathrm{L}$ \\
\hline $\mathrm{I} / 3$ & Podzamcze & $\mathrm{L}$ & $\mathrm{L}$ & $\mathrm{L}$ & M & M \\
\hline $\mathrm{II} / 1$ & Rybaki & $\mathrm{M}$ & $\mathrm{L}$ & $\mathrm{H}$ & $\mathrm{H}$ & $\mathrm{M}$ \\
\hline $\mathrm{II} / 2$ & Bulwar Inflancki N & $\mathrm{M}$ & $\mathrm{M}$ & $\mathrm{H}$ & $\mathrm{M}$ & $\mathrm{M}$ \\
\hline $\mathrm{II} / 3$ & Bulwar Inflancki S & $\mathrm{M}$ & $\mathrm{H}$ & $\mathrm{H}$ & M & M \\
\hline $\mathrm{II} / 4$ & Bulwar Kurlandzki & $\mathrm{M}$ & $\mathrm{H}$ & $\mathrm{H}$ & $\mathrm{M}$ & $\mathrm{M}$ \\
\hline
\end{tabular}

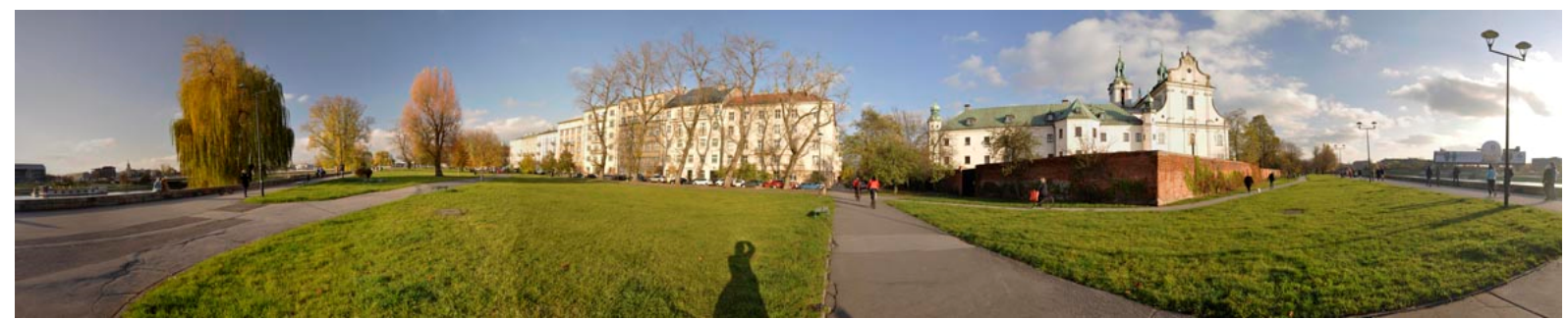

Figure 7. Composition elements of the WAK II/2, 1. Distance (M), 2. View depth (M), 3. Width (H), 4. Multiplanning (M), 5. Presence of borrowed views (M).

\subsubsection{Visual Pollution}

Due to significant differences between the state of the substance, the composition value, and neglect of the public sphere due to intensive use, an additional aspect of the characteristics of the study area was identified, namely the visual pollution index. The assessed elements here are those that have become layered as a result of neglect in maintenance, elements that distinguish themselves in urban space or temporary elements. They do not constitute historical substance nor do they belong to the main urban structure, yet they decide about the visual reception of townscape, so they are treated as a separate category. They are presented as the degree of visual pollution of urban space. The level of pollution is impacted by elements observed in space and their intensity on the three-grade scale: high, medium, and low. Among those elements, we distinguish the following: 1. Neglected surfaces, 2. Neglected facades, 3. Chaotic street furniture, 4. Neglected and chaotic greenery, 5. Presence of outdoor advertisement, 6. Excess of road signs, 7. Burdensome presence of parked vehicles (Table 4).

Table 4. Visual pollution listed for particular enclosures 1. Neglected surfaces, 2. Neglected facades, 3. Chaotic street furniture, 4. Neglected and chaotic greenery, 5. Presence of outdoor advertisement, 6. Excess of road signs, 7. Burdensome presence of parked vehicles.

\begin{tabular}{|c|c|c|c|c|c|c|c|c|c|}
\hline \multirow{2}{*}{ ZWAK } & \multirow{2}{*}{ WAK } & \multicolumn{7}{|c|}{ Elements } & \multirow{2}{*}{$\begin{array}{c}\text { Pollution } \\
\text { Degree }\end{array}$} \\
\hline & & 1 & 2 & 3 & 4 & 5 & 6 & 7 & \\
\hline $\mathrm{I} / 1$ & Wistula band & $\mathrm{L}$ & & & & $M$ & & & $\mathrm{~L}$ \\
\hline $\mathrm{I} / 2$ & Na Groblach Sqare & & & & $\mathrm{L}$ & $\mathrm{L}$ & & M & $\mathrm{L}$ \\
\hline $\mathrm{I} / 3$ & Podzamcze & & & & & & & $\mathrm{L}$ & $\mathrm{L}$ \\
\hline
\end{tabular}


Table 4. Cont.

\begin{tabular}{|c|c|c|c|c|c|c|c|c|c|}
\hline \multirow{2}{*}{ ZWAK } & \multirow{2}{*}{ WAK } & \multicolumn{7}{|c|}{ Elements } & \multirow{2}{*}{$\begin{array}{c}\text { Pollution } \\
\text { Degree }\end{array}$} \\
\hline & & 1 & 2 & 3 & 4 & 5 & 6 & 7 & \\
\hline $\mathrm{II} / 1$ & Rybaki & M & & & & $\mathrm{L}$ & & & $\mathrm{L}$ \\
\hline $\mathrm{II} / 2$ & Bulwar Inflancki Pn & $\mathrm{L}$ & & & & $\mathrm{L}$ & & & $\mathrm{L}$ \\
\hline $\mathrm{II} / 3$ & Bulwar Inflancki Pd & $\mathrm{M}$ & & & & $\mathrm{H}+$ & & & $\mathrm{L}$ \\
\hline $\mathrm{II} / 4$ & Bulwar Kurlandzki & M & & & & $\mathrm{L}$ & $\mathrm{L}$ & & $\mathrm{L}$ \\
\hline III.1 & Bernardyni & $\mathrm{L}$ & & $\mathrm{L}$ & & $\mathrm{L}$ & $\mathrm{M}$ & $\mathrm{M}$ & M \\
\hline III. 2 & Misjonarze & & & & & & & & $\mathrm{L}$ \\
\hline III.3 & Bożogrobcy & $\mathrm{L}$ & & & & $\mathrm{M}$ & 1 & $\mathrm{M}$ & M \\
\hline III. 4 & Piekiełko & M & $\mathrm{L}$ & $\mathrm{M}$ & $\mathrm{L}$ & M & $\mathrm{M}$ & & M \\
\hline III. 5 & Koletki & & $\mathrm{L}$ & & & & $\mathrm{M}$ & $\mathrm{L}$ & $\mathrm{L}$ \\
\hline III.6 & Nadwiślan & $\mathrm{L}$ & $\mathrm{H}$ & $\mathrm{H}$ & $\mathrm{L}$ & $\mathrm{H}$ & $\mathrm{M}$ & & $\mathrm{H}$ \\
\hline IV.1 & Starowiślna & M & $\mathrm{L}$ & $\mathrm{H}$ & $\mathrm{L}$ & $\mathrm{M}$ & $\mathrm{L}$ & $\mathrm{H}$ & $\mathrm{H}$ \\
\hline IV.2 & Świętego Sebastiana & M & & $\mathrm{L}$ & $\mathrm{L}$ & & & $\mathrm{M}$ & $\mathrm{L}$ \\
\hline V.1 & Wrzesińska & M & $\mathrm{L}$ & $\mathrm{H}$ & $\mathrm{H}$ & & & $\mathrm{M}$ & $\mathrm{H}$ \\
\hline V.2 & Berka Joselewicza & $\mathrm{H}$ & $\mathrm{M}$ & $\mathrm{H}$ & $\mathrm{H}$ & $\mathrm{H}$ & $\mathrm{L}$ & $\mathrm{H}$ & $\mathrm{H}$ \\
\hline V.3 & Dietla Pn & $\mathrm{r}$ & M & $\mathrm{M}$ & & $\mathrm{H}$ & $\mathrm{M}$ & & M \\
\hline V.4 & Dietla Pd & & & $\mathrm{L}$ & $\mathrm{L}$ & $\mathrm{M}$ & $\mathrm{H}$ & $\mathrm{M}$ & M \\
\hline VI.1 & Dajwór & M & $\mathrm{M}$ & & & $\mathrm{M}$ & $\mathrm{M}$ & $\mathrm{M}$ & $\mathrm{H}$ \\
\hline VI.2 & Halicka & $\mathrm{H}$ & $\mathrm{M}$ & $\mathrm{H}$ & $\mathrm{H}$ & & & $\mathrm{H}$ & $\mathrm{H}$ \\
\hline VII.1 & Szeroka & $\mathrm{M}$ & & $\mathrm{H}$ & M & $\mathrm{H}$ & $\mathrm{M}$ & $\mathrm{H}$ & $\mathrm{H}$ \\
\hline VII. 2 & Bawół & & M & $\mathrm{M}$ & & $\mathrm{M}$ & $\mathrm{M}$ & & M \\
\hline VII.3 & Plac Nowy & $\mathrm{H}$ & $\mathrm{M}$ & $\mathrm{H}$ & $\mathrm{L}$ & $\mathrm{H}$ & $\mathrm{H}$ & $\mathrm{H}$ & $\mathrm{H}$ \\
\hline VII.4 & Miodowa & $\mathrm{H}$ & $\mathrm{M}$ & $\mathrm{H}$ & $\mathrm{H}$ & $\mathrm{H}$ & $\mathrm{M}$ & $\mathrm{M}$ & $\mathrm{H}$ \\
\hline VII.5 & Brzozowa & $\mathrm{H}$ & M & $\mathrm{H}$ & $\mathrm{H}$ & $\mathrm{H}$ & $\mathrm{M}$ & $\mathrm{H}$ & $\mathrm{H}$ \\
\hline VIII.1 & Zajezdnia & & & & & $\mathrm{M}$ & 1 & & $\mathrm{~L}$ \\
\hline VIII.2 & Gazownia & & & & & $\mathrm{L}$ & $\mathrm{L}$ & $\mathrm{M}$ & $\mathrm{L}$ \\
\hline VIII.3 & Elektrownia & & & & & & $\mathrm{L}$ & $\mathrm{M}$ & $\mathrm{L}$ \\
\hline IX.1 & Skałka & M & & & & & & $\mathrm{L}$ & $\mathrm{L}$ \\
\hline IX.2 & Augustianie & & $\mathrm{H}$ & & & & $\mathrm{L}$ & $\mathrm{H}$ & $\mathrm{L}$ \\
\hline IX.3 & Piekarska & $\mathrm{L}$ & & & & & & $\mathrm{M}$ & $\mathrm{L}$ \\
\hline IX.4 & Skawińska & $\mathrm{L}$ & & & & & $\mathrm{M}$ & $\mathrm{H}$ & M \\
\hline IX.5 & Krakowska Zach & & & $\mathrm{L}$ & & $\mathrm{M}$ & $\mathrm{L}$ & $\mathrm{M}$ & $\mathrm{L}$ \\
\hline IX.6 & Krakowska Wsch & $\mathrm{H}$ & $\mathrm{H}$ & $\mathrm{M}$ & & $\mathrm{H}$ & $\mathrm{M}$ & - & $\mathrm{H}$ \\
\hline IX.7 & Bożego Ciała & $\mathrm{H}$ & $\mathrm{M}$ & $\mathrm{M}$ & & $\mathrm{H}$ & $\mathrm{M}$ & $\mathrm{H}$ & $\mathrm{H}$ \\
\hline IX.8 & Wolnica & $\mathrm{H}$ & $\mathrm{L}$ & $\mathrm{M}$ & M & $\mathrm{M}$ & $\mathrm{M}$ & $\mathrm{H}$ & $\mathrm{H}$ \\
\hline IX.9 & Bonifratrzy & $\mathrm{L}$ & & & $\mathrm{L}$ & & $\mathrm{L}$ & & $\mathrm{L}$ \\
\hline IX.10 & Mostowa & & & & $\mathrm{L}$ & $\mathrm{L}$ & $\mathrm{L}$ & $\mathrm{M}$ & $\mathrm{L}$ \\
\hline
\end{tabular}

\subsection{Assessment of Visual Values}

Baseline analyses became the basis for active exposure assessment. The elements of active exposure became the criteria of assessment of active exposure. The elements' layout and layering indicated enclosures with the most precious views. Those views are the district's landmarks. Their location shapes tourist routes and decides the concentration of services in the public sphere while indicating the need for more intensive management. The assessment criteria were the number and rank of elements of active exposure. Depending on the number of elements, the active exposure value can range from the highest, through high, medium, low up to the lowest value.

The value of passive exposure is estimated on the basis of compositional character and the quality of historical substance which was decided upon by studied by historians. The accepted criteria of composition characteristics allowed us to define and assess them in the case of particular enclosures. Distance, depth, width, multiplanning, and borrowed 
views helped us to characterize the richness of passive exposure and define the enclosure value in this respect.

Listing the values of passive and active exposure became the basis for the assessment of exposure of particular enclosures (Table 5).

Table 5. Active and passive exposure evaluation summary.

\begin{tabular}{|c|c|c|c|c|}
\hline & \multicolumn{4}{|c|}{ Active Exposure } \\
\hline & & High & Medium & Low \\
\hline \multirow{3}{*}{ Passive Exposure } & High & Highest & High & Medium \\
\hline & Medium & High & Medium & Low \\
\hline & Low & Medium & Low & Lowest \\
\hline
\end{tabular}

The studies allowed us to obtain information regarding the resources and characterize architectural and landscape enclosures (WAK). As a result, an assessment of active and passive exposure was made as well as a summary assessment which allowed for zoning out the study area (Figure 8).

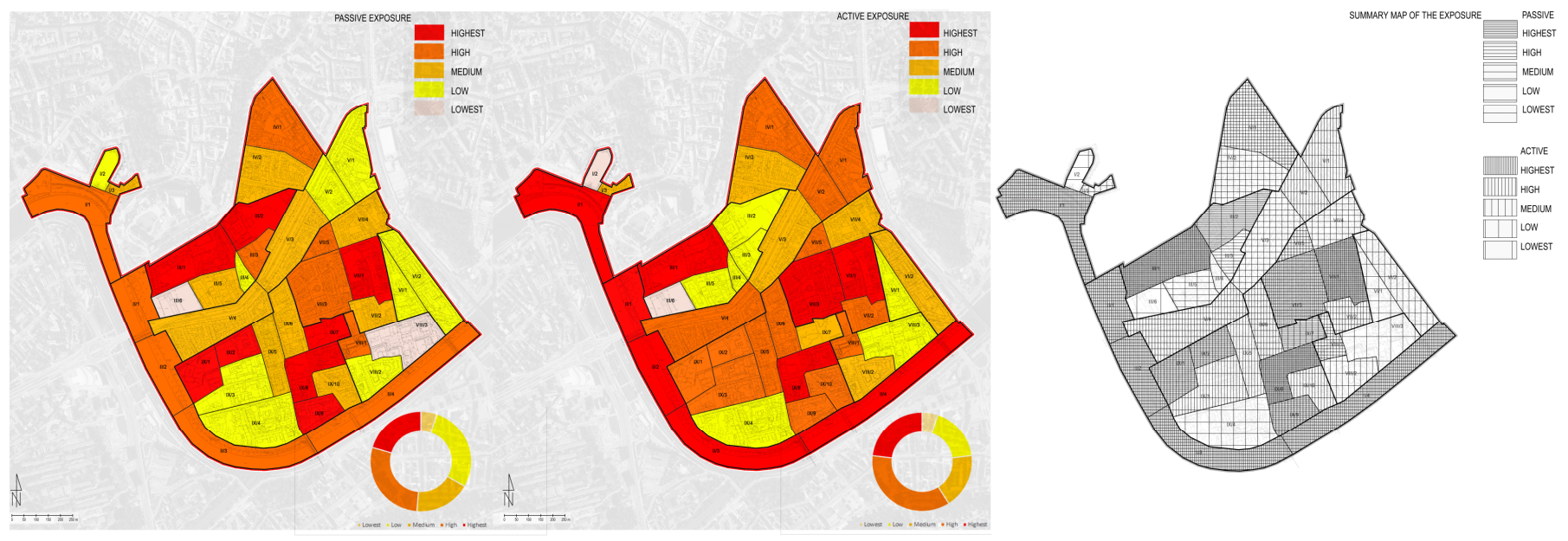

Figure 8. Assessment map of active and passive exposure and summary map.

The applied method allowed us to distinguish characteristic features of the urban structure. While basing on the key role of dominants and subdominants in the city [41,42] and defining their visibility degree [43], an analysis was made of the urban structure leading to creating a hierarchy of elements of active exposure. Comparing the analyses made on this basis for various spaces indicates how effective this method is and it allows us to distinguish characteristic features of the analyzed space and their assessment at a further stage. A graphic analysis of the elements of active exposure brought about some interesting results. The graphic form of the presentation showed visual characteristics of the area. It helped to define the character of internal visual connections, their range and intensity of occurrence. Moreover, it illustrated the openness of the analysed district towards neighbouring parts of the urban structure. In the case of Stradom and Kazimierz, the number of visual connections is high and it is determined by the presence of dominants and subdominants as well as the urban layout. This district also shows unique connections with neighbouring districts. This is due to the proximity to the Vistula riverbed and the shape of the surface of the river valley which provides for long views reaching the hills.

An analysis of passive and active exposure led to separating enclosures by value, which was shown in the form of the map, the table and the diagrams.

Valuing that takes into account the issues of active exposure as well as substance value and its visual realisation as passive exposure made it possible to divide the area of the 
Cultural Park in accordance with five value categories. On this basis, we distinguished a zone of special exposure value with the highest values in terms of composition and substance as well as an abundance of sites of active exposure.

Further stages of analyses became the basis for formulating project guidelines. They were related to active and passive exposure and came down to preserving and protecting existing visual connections, clearing the vanishing or losing clarity views, subjecting foreground of the view and clearing particular view plans.

Based on this hierarchy of elements of active exposure, key views very important for historic urban space were indicated. Their identification was the basis for the Cultural Park managing project and for the preparation of impact assessments for new development proposals [6]. The research also indicated monitoring points for landscape changes [26]. For every group of enclosures, one monitoring point was indicated. Guidelines related to monitoring were applied in urban space while using the experience gained during studies of open protected areas.

As a result of the analysis of view, pollution information was obtained regarding the degree of pollution and its territorial layout (Figure 9). Comparing exposure assessment to the visual pollution degree provided us with additional data. Places with the highest visual pollution were identified. It was also possible to observe against which exposition values pollution takes place. It occurred that in several cases, the highest visual pollution affects enclosures with the highest exposition values. At the same time, little visual pollution covers enclosures that could boast medium to low visual values. These observations became the basis for marking out intervention zones within the studied area. There are zones of immediate intervention and moderate intervention. Immediate intervention zones are those which cover the highest degree of view pollution and the highest exposition values (Figure 10).

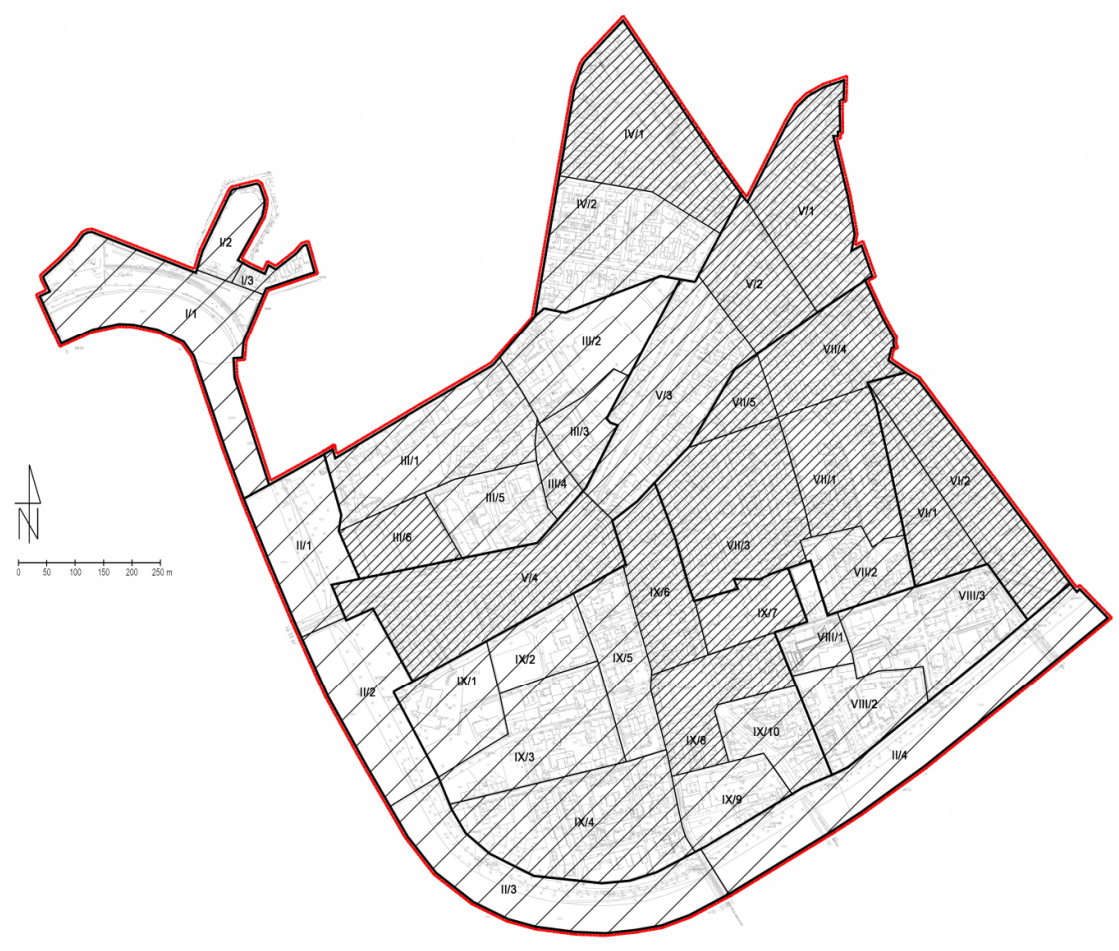

Figure 9. Degree of view pollution.
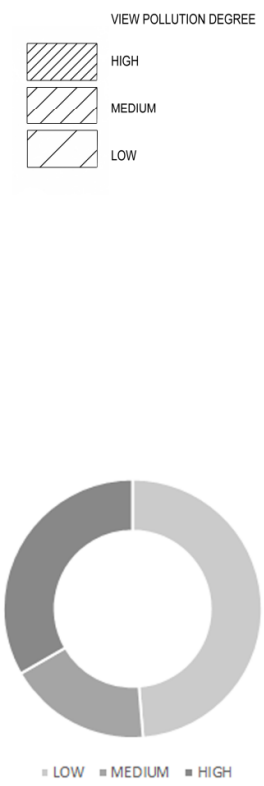

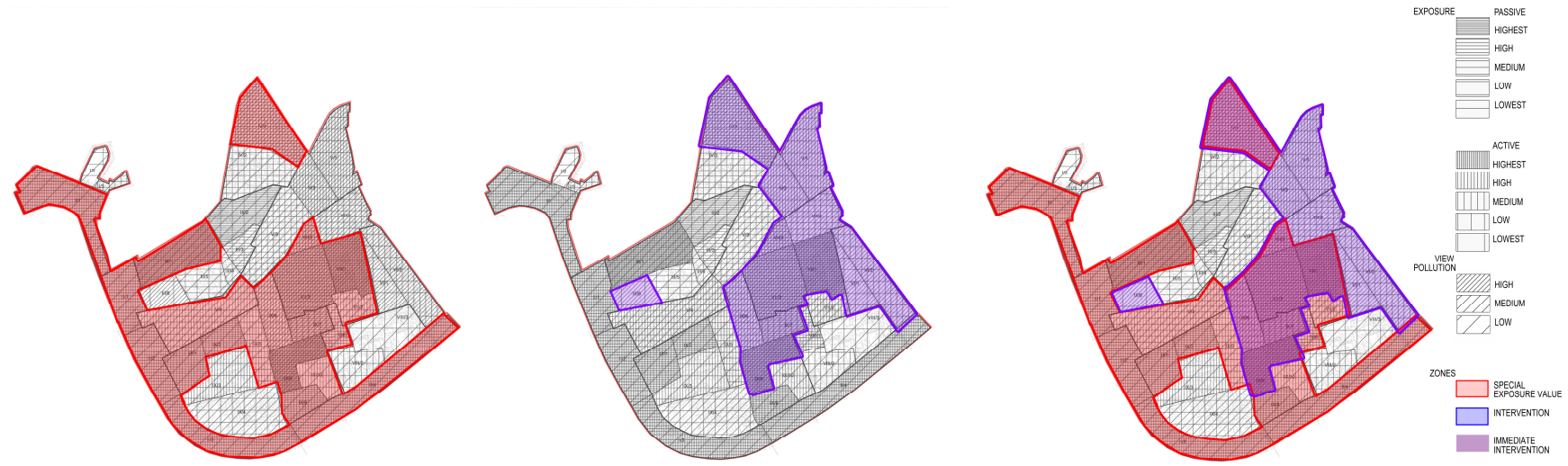

Figure 10. Zone with the highest exposure values, zone of intervention and zone of immediate intervention.

These observations distinguish the Cultural Park protection plan for Stradom and Kazimierz against the previously prepared protection plans. Individual characteristic features of the place indicated the need for developing a certain method and adjusting the tools to the nature of the place.

\section{Discussion}

Visual studies of urban substance are conducted with the use of various methods and to varying degrees. They use available digital tools and various types of analyses. Moreover, they present a different degree of detail. Advanced tools are used for in-depth studies of spatial phenomena and their impact on the functioning of the city [63] and open landscape [64]. The development of those methods is very dynamic and varied [19]. In Poland, such studies are usually conducted as expert opinions focusing on selected issues, such as urban panorama against new investments [65] or an influence of a high-rise building on spatial relations [50] as well as the degree of shading the area as a result of new investment [66]. They are related to commercial investment in real estate development or single buildings. Comprehensive analyses of whole districts or cities which could become a part of a local zoning plan are currently hardly ever carried out. According to Różycka [67], currently, we are dealing with a crisis of the modern planning system in Poland. Due to that fact, valuable urban substances require our special attention.

The form of protection as a Cultural Park and its implementation as a cultural park protection plan fills this void. It creates possibilities for development and comprehensive visual analysis of areas of high spatial values as indicated by Z. Myczkowski and others [3]. While being a starting document for a local zoning plan, it provides for the application of the results in the plan which then becomes an act of local law.

The presented method demonstrates the way of using possibilities that the protection plan offers in terms of visual values of urban structure. A comprehensive approach to visual analysis was presented as it combines contemporary achievements of visual analyses when it comes to visual assessment with KSLA assumptions where the landscape is treated as a spatial form. This fusion demonstrates an original approach to landscape represented by the field of landscape architecture. This work uses achievements in the field of analyses of urban structures [38]; it also creates a division into landscape units with reference to urban structure. At the same time, it applies the methods related to protected areas as suggested by Palmer that landscape observation and control are the basis for following processes and on their basis, effective actions can be undertaken [41].

Special attention should be given to a graphic interpretation of the results of the active exposure analysis. It acted as an exceptional comparative material to demonstrate the nature of visual connections of the analysed area, both internal connections and external ones. This form of graphic interpretation is appreciated by both designers and planners [68]. The one used in this case exposes composition and spatial specifics while reflecting uniformity or complexity of spatial structure. It visualises the degree of the visual connection with 
external structures. In this way, it shows critical directions and helps to adequately channel the course of action. The diagrams present a comparison of three Krakow districts, namely: Old Town, Nowa Huta, Stradom and Kazimierz (Figure 11).

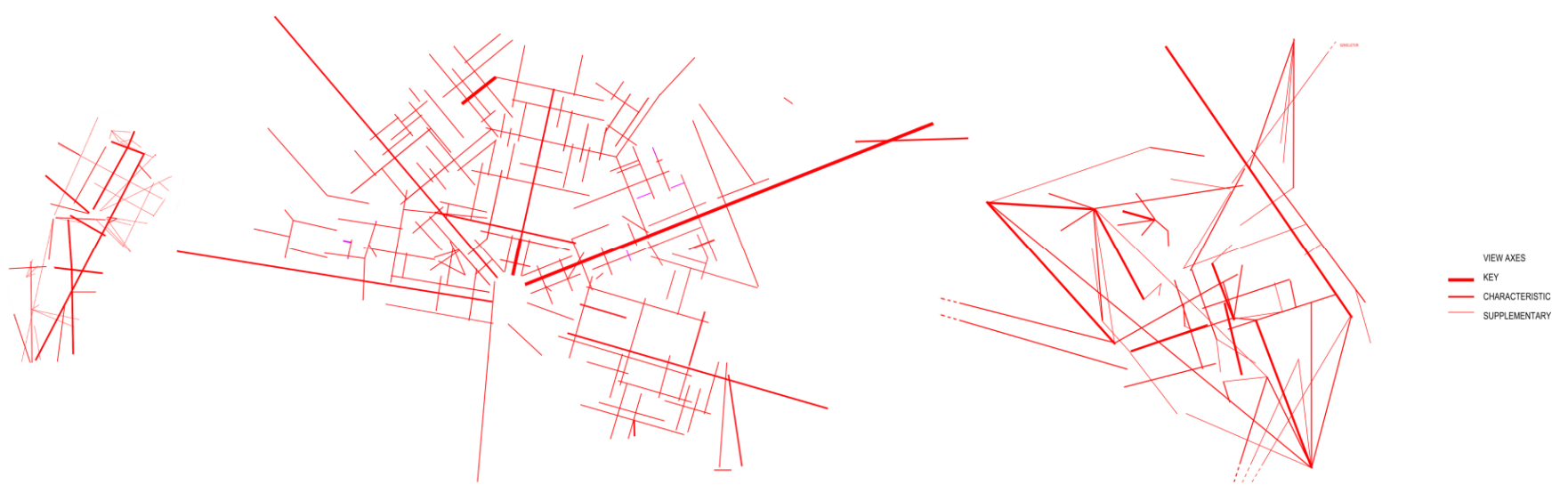

Figure 11. Comparison of the diagram of visual axes for Old Town, Nowa Huta, Stradom and Kazimierz.

The presented example of the visual analysis put together the experience of past visual analyses for Cultural Parks. On the other hand, it contributed to an evolution in the developed method. The source of this evolution was the recording and characterising of the place as well as the need to take those into account in the study process. In this case, it was a place of rich substance and compositional values, but also neglected and deprived of adequate management. Developed enlargement of the method creates new possibilities for its use. With reference to space of high values exposed to intensive use observations prove that combining these characteristics goes hand in hand with a lack of adequate regulations for use which poses a threat to landscape values and calls for immediate intervention.

The evolution of the method demonstrates its flexibility and that it can adjust to working conditions and individual characteristic features of the analysed area which is perceived as an advantage by the authors of the guidelines for the assessment of landscape impact (GLVIA). It is based on the cooperation of experts across different areas of expertise which ensures a contemporary multithreaded approach, which is crucial in the case of studying complex urban structures [69].

The need for these types of studies in a modern city is stressed by T. Brigen who indicates that the view as such is today a multi-aspect value. It has become a common quality whose value crosses the borders of not only the city but often the country which at the same time constitutes the self-portrait of its community. Proper legal protection of the view has a cultural and financial effect on a different scale. The view is that heritage constitutes not only one's cultural identity and personal aesthetic experience but also the popularity of the city, tourism and property management [70].

It is key in terms of intensive urban development and strong pro-investment lobby movements. The legitimacy of this type of analysis is proved in widely criticised cases of destroying visual axes in the cities, as in Warsaw in the case of the Saska axis. In this context, the issue of protecting the view as a cultural resource and developing transparent methods of identifying and assessing the value of a view becomes key [15].

The presented paper touches upon the issue of scenic values, whose role is crucial in a modern city. This is confirmed by the provisions of UNESCO's declarations and recommendations, which pay more and more attention to the context and the perceived landscape [2,28]. In Krakow, this problem is particularly important in view of very strong investment pressure and the generally poor condition of the planning system in Poland [71] in the context of enormous tourist traffic [56]. Krakow represents a city of very high historical value. On the one hand, this creates both economic and social opportunities; yet, on the other hand, it threatens the substance and its material and non-material values [72]. 
Overexploitation of tourism, investment pressure, and loss of permanent residents are processes still present and requiring regulation. These phenomena can be observed in Eastern European cities in, for example, Croatia, Romania and Bulgaria [73]. In turn, the problem of migration from cities, gentrification and loss of identity in the social dimension also affects other parts of Europe and the world requires more and more effective forms of protection [2,29]. In this context, urban landscape visibility constitutes a link between the future and the past well remembered $[26,69,73]$. While it evokes reactions at the social and economic level, it is unquestionably a landscape resource [2]. Moreover, visual balance is indicated in numerous sources as a picture of sustainable landscape management $[1,46]$ and since it is a resource, it can be lost if inadequately managed.

\section{Conclusions}

The demonstrated example of a visual analysis prepared for the cultural park protection plan project presents a comprehensive study method.

Visual analysis in this case, while being based on the achievements of the Krakow School of Landscape Architecture as well as contemporary methods developed as a part of visual assessment, provided for adjusting tools to the needs of the analysis [34]. Meanwhile, combining knowledge regarding historical substance value and spatial dependencies with the use of contemporary study tools allows for a balanced approach that favourably connects the accessible methods.

The developed methodical scheme dedicated to the visual analysis of urban space presents subsequent stages and the scope of works. Its formula creates possibilities for adjusting detailed studies to the specifics of the analysed area. Its application allows for distinguishing characteristic visual features of particular spaces. These features have a significant meaning for further landscape development and management in the spirit of sustainable development which is to preserve the most precious visual resources for protection and securing diversity of cultural heritage and landscape.

It allows us to preserve individual visual features and preserve spatial diversity which leads to the creation of space for sustainable spatial development while keeping its visual identity. This is in line with the recommendations for UNESCO sites, allowing for the study of the broad spatial context of the most valuable urban structures.

It provides arguments for a discussion on specific cases, which is crucial in times of aggressive real estate development policy.

The case invoked proved the effectiveness of applying a chain of studies according to the accepted order, and at the same time, it pointed to the legitimacy of using visual analyses that support project decisions in protection plans. The evolution of the method indicates its versatility and usefulness in terms of analysing diverse urban spaces.

The applied form allows for further verification and development based on studies of space with individual features.

Funding: This research received no external funding.

Institutional Review Board Statement: Not applicable.

Informed Consent Statement: Not applicable.

Data Availability Statement: Not applicable.

Acknowledgments: The author would like to thank the entire team developing the project of Protection plan of the Stradom and Kazimierz Cultural Park for the cooperation. The author express gratitude to the reviewers, whose remarks and suggestions have helped to improve the work.

Conflicts of Interest: The author declares no conflict of interest. 


\section{References}

1. UNESCO. Recommendation on the Historic Urban Landscape; UNESCO: Paris, France, 2011. Available online: https:/ / whc.unesco. org/en/hul/ (accessed on 1 June 2021).

2. Myczkowski, Z.; Marcinek, R.; Siwek, A. Park Kulturowy Jako Forma Ochrony Krajobrazu Kulturowego (en. Cultural Park as a Form of Cultural Landscape Protection); OT NID Press: Kraków, Poland, 2017.

3. Ustawa O Ochronie Zabytków I Opiece Nad Zabytkami Z dn. 3 Lipca 2003 Roku (en. Act on the Protection and Care of Monuments). 2003. Available online: http:/ / isap.sejm.gov.pl/isap.nsf/DocDetails.xsp?id=WDu20030800717 (accessed on 20 May 2021).

4. European Landscape Convention, European Treaty Series-No. 176; Council of Europe: Florence, Italy, 2000. Available online: https: / /rm.coe.int/1680080621 (accessed on 26 December 2020).

5. Forczek-Brataniec, U. Visible Space: A Visual Analysis in the Lanscape Planning and Designing; Cracow University of Technology: Cracow, Poland, 2018.

6. González, A.P. Cultural Parks and National Heritage Areas: Assembling Cultural Heritage, Development and Spatial Planning; Cambridge Scholars Publishing: Newcastle, UK, 2013.

7. Lynch, K. The Image of the City, 1st ed.; The MIT Press: Cambridge, MA, USA, 1960.

8. Cullen, G. Concise Townscape, 1st ed.; Routledge Press: New York, NY, USA, 1961.

9. Jackle, J.A. The Visual Elements of Landscape, 1st ed.; The University of Massachusetts Press: Amherst, MA, USA, 1987.

10. Bell, S. Elements of Visual Design in the Landscape, 2nd ed.; Spon Press: London, UK, 2004.

11. Iwańczak, B.; Lewicka, M. Affective map of Warsaw: Testing Aleksander's pattern language theory in an urban landscape. Landsc. Urban Plan. 2020, 204, 1-16. [CrossRef]

12. Mordwa, S. Krzywa wrażeń dla ulicy Piotrowskiej w Łodzi (en. Piotrkowska Street In Łódź Sensations Curve). Acta Univ. Lodz. Folia Geogr. Econ. 2009, 10, 89-98.

13. Wejchert, K. Elementy Kompozycji Urbanistycznej (en. Elements of Urban Composition); Arkady: Warsaw, Poland, 1984.

14. Green, S. Seeing the History in the View, a Method for Assessing Heritage Significance Within Views, 1st ed.; English Heritage: London, UK, 2011.

15. Sternberg, E.H. Healing Spaces: The Science of Place and Well-Being; Harvard University Press: Cambridge, MA, USA, 2010.

16. Antrop, M. Geography and landscape science. Belgeo 2000, 30, 9-36. [CrossRef]

17. Tuan, Y.F. Space and Place: The Perspective of Experience, 1st ed.; University of Minnesota Press: Minneapolis, MN, USA, 1977.

18. Vidal de La Blache, P. Principes de Géographie Humaine: Publiés d'après les Manuscrits de l'auteur par Emmanuel de Martonne; ENS Édition: Lyon, France, 2015.

19. Livingstone, D.N. Classics in human geography revisited: Commentary. Prog. Hum. Geogr. 1994, 18, 209-210. [CrossRef]

20. González, A.P. From a given to a construct: Heritage as a commons. Cult. Stud. 2014, 28, 359-390. [CrossRef]

21. Parga-Dans, E.; Gonzales, P.A.; Enriguez, R.O. The social value of heritage: Balancing the promotion-preservation relationship in the Altamira World Heritage Site, Spain. J. Destin. Mark. 2020, 18, 10499. [CrossRef]

22. Szpakowska-Loranc, E.; Matusik, A. Łódź-Towards a resilient city. Cities 2020, 107, 102936. [CrossRef]

23. Czyńska, K. Ksztattowanie Wspótczesnych Panoram Miast na Przykładzie Szczecina. Wykorzystanie Wirtualnych Modeli Miast w Monitoringu i Symulacji Panoram (en. Using Model of Virtual City for Research on Visibility Range of Panoramas of the City); Uniwersytet Wrocławski: Wrocław, Poland, 2006.

24. Sroczyńska, J. The Social Value of Architectural Monuments in the Light of Selected Documents of UNESCO Icomos, the Council of Europe, Shaping the Theory of Cultural Heritage Protection. Wiadomości Konserw. J. Herit. Conserv. 2021, 65, 7-19.

25. Kobayashi, A. A Critique of Dialectical Landscape. In Remaking Human Geography (RLE Social E Cultural Geography), 1st ed.; Kobayashi, A., Mackenzie, S., Eds.; Routledge: London, UK, 1989.

26. Cosgrove, D.F. Social Formation and Symbolic Landscape, 2nd ed.; The University of Wisconsin Press: Madison, WI, USA, 1998.

27. UNESCO. Recommendation Concerning the Safeguarding of Beauty and Character of Landscapes and Sites, Paris; UNESCO: Paris, France, 1962. Available online: https:// unesdoc.unesco.org/ark:/48223/pf0000114582.page=142 (accessed on 1 June 2021).

28. ICOMOS Xi' an Declaration on the Conservation of the Setting of Heritage Structures, Sites and Areas. Available online: http:/ / orcp.hustoj.com/the-xian-declaration-on-the-conservation-of-the-setting-of-heritage-structures-sites-and-areas-2005/ (accessed on 1 June 2021).

29. ICOMOS. Heritage and Landscape as Human Values, Florence; ICOMOS: Florence, Italy, 2014. Available online: https:/ /www.icomos. org/en/about-icomos/2016-11-17-13-14-08/minutes-of-the-general-assemblies (accessed on 1 June 2021).

30. Voronych, Y. Visual Pollution of urban space in Lviv. Przestrz. Forma 2013, 20, 309-314.

31. Zube, E.H.; Brush, R.O. Landscape Assessment: Values, Perceptions and Resources, 1st ed.; Zube, E.H., Brush, R.O., Fabos, J.G., Eds.; Dowden, Hutchinson \& Ross: Stroudsburg, PA, USA, 1975.

32. Gobster, P.H.; Ribe Robert, G.; Palmer, J.F. Themes and trends in visual assessment research: Introduction to the "Landscape and Urban Planning special collection on the visual assessment of landscapes. Landsc. Urban Plan. 2019, 191, 1-7. [CrossRef]

33. Swanwick, C. Guidelines for Landscape and Visual Impact Assessment, 3rd ed.; Routledge: London, UK, 2013.

34. Ozimek, P.; Böhm, A.; Ozimek, A.; Wańkowicz, W. Planowanie Przestrzeni o Wysokich Walorach Krajobrazowych Przy Użyciu Cyfrowych Analiz Terenu Wraz z Ocena Ekonomiczna (en. Planning Spaces with High Scenic Values by Means of Digital Terrain Analyses and Economic Evaluation); Cracow University of Technology: Cracow, Poland, 2013. 
35. Ozimek, P.; Ozimek, A. Viewshed Analyses as Support for Objective Landscape Assessment. J. Digit. Landsc. Archit. 2017, 2, 190-197.

36. Photography and Photomontage in Landscape and Visual Impact Assessment. Available online: https:/ / landscapewpstorage0 1.blob.core.windows.net/www-landscapeinstitute-org/2019/01/LIPhotographyAdviceNote01-11.pdf (accessed on 1 November 2019).

37. Szczepańska, A.; Pietrzyk, K.; Senetra, A. Analysis and Evaluation of Historical Public Spaces in Small Towns in the Polish Region of Warmia. Sustainability 2020, 12, 8356.

38. Górka, A. Visual Capacity Assessment of the Open Landscape in Terms of Protection and Shaping: Case Study of a Village in Poland. Sustainability 2020, 12, 6319. [CrossRef]

39. Litton, R.B. Landscape Control Points: A Procedure for Predicting and Monitoring Visual Impacts; Pacific Southwest Forest and Range Exp.Stn.: Berkeley, CA, USA, 1973.

40. Palmer James, F. The contribution of key observation point evaluation to a scientifically rigorous approach to visual impact assessment. Landsc. Urban Plan. 2019, 183, 100-110. [CrossRef]

41. Bogdanowski, J. Kompozycja i Planowanie w Architekturze Krajobrazu (en. Composition and Planning in Landscape Architecture), 1st ed.; Zakład Narodowy Im. Ossolińskich: Wrocław, Poland, 1976.

42. Myczkowski, Z.; Forczek-Brataniec, U.; Chajdys, K.; Rymsza-Mazur, W.; Środulska-Wielgus, J.; Wielgus, K. Metoda jednostek i wnętrz architektoniczno-krajobrazowych (JARK-WAK) w relacjach XXI wieku (en. JARK-WAK $2000+$ the method of landscape architectural units and interiors on the background of researches in XXI century). In Metoda Architektury Krajobrazu; Szulczewska, B., Szumański, M., Eds.; Wieś Jutra Press: Warszawa, Poland, 2010; pp. 7-15.

43. Bogdanowski, J. Metoda Jednostek $i$ Wnętrz Architektoniczno-Krajobrazowych (JARK-WAK) w Studiach i Projektowaniu (en. The Units and Rooms Method (JARK-WAK) in Studies and Design), 2nd ed.; Cracow University of Technology: Cracow, Poland, 1990.

44. Dabrowska-Budziło, K. Treść krajobrazu Kulturowego w Jego Kształtowaniu i Ochronie (en. Symbolism of the Cultural Landscape in Its Shaping and Protection); Cracow University of Technology: Cracow, Poland, 2002.

45. Myczkowski, Z.; Forczek-Brataniec, U. Landscape conservation in the research and development of the Krakow School of landscape architecture from 1970s to 2017-From Jurassic landscape parks to cultural parks in Krakow. Landsc. Archit. Art 2018, 13, 129-134.

46. Forczek-Brataniec, U. Zmiany w krajobrazie wokół zbiorników wodnych w Pieninach. Monogr. Pienińskie 2010, 2, $259-279$.

47. Czyńska, K.; Rubinowicz, P. Sky Tower impact on the landscape of Wrocław-Analysing based on the VIS method. Architectus 2017, 50, 87-98.

48. Oleński, W. Postrzeganie Krajobrazu Miasta w Warunkach Wertykalizacji Zabudowy (en. The Perception of Cityscape in the Environment of Verticalization of Buildings). Biblioteka Cyfrowa Politechniki Krakowskiej. Available online: https:// repozytorium.biblos.pk.edu.pl/resources/26294 (accessed on 1 November 2019).

49. Czyńska, K.; Rubinowicz, P. Application of 3D virtual city models in urban analyses of tall buildings-Today practice and future challenges. Archtecurae Artibus 2014, 19, 9-13.

50. Rubinowicz, P.; Czyńska, K. Study of City Landscape Heritage Using Lidar Data and 3d-City Models, The International Archives of the Photogrammetry. Remote Sens. Spat. Form. Sci. 2015, XL-7/W3, 1395-1402.

51. Szczepańska, A.; Pietrzyk, K. Evaluation of public spaces in historical centers of small towns-Case study. J. Urban Plan. Dev. 2020, 146, 05019020. [CrossRef]

52. Adamczewski, J. Mała Encyklopedia Krakowa (en. Little Encyclopedia of Krakow); Wanda Press: Kraków, Poland, 1997.

53. Marcinek, R.; Myczkowski, Z.; Bohm, A. Bulwary Wiślane; OKiCKN Press: Kraków, Poland, 2012.

54. Bieniarzówna, J.; Małecki, J.M. Dzieje Krakowa. Tom 3. Kraków w latach 1796-1918 (The History of Krakow. Volume 3: Krakow in the years 1796-1918); Wydawnictwo Literackie: Krakow, Poland, 1994.

55. Kraków w Liczbach (Krakow in Figures). 2019. Available online: https://www.bip.krakow.pl/?mmi=6353 (accessed on 1 November 2020).

56. Palmer James, F. A Landscape Assessment Framework for Visual Impact Assessment in the USA. J. Digit. Landsc. Archit. 2016, $1,10-17$.

57. Myczkowski, Z.; Forczek-Brataniec, U.; Wielgus, K. Plan ochrony Parku Kulturowego Stare Miasto w Krakowie w kontekście ochrony i planowania krajobrazu miasta (en. Protection plan of Cultural Park of Downtown of Cracow in the context of conservation and planning of townscape). In Planowanie Krajobrazu: Wybrane Zagadnienia; Przesmycka, E., Ed.; Wydawnictwo Uniwersytetu Przyrodniczego w Lublinie: Lublin, Poland, 2013; pp. 38-60.

58. Ozimek, A. Landscape Measure. Objectification of Views and Panoramas Assessment Supported by Computer Tools, 1st ed.; Cracow University of Technology: Cracow, Poland, 2019.

59. Graczyk, R. Identyfikacyjna Funkcja Dominanty Architektonicznej w Strukturze Matego Miasta (en. Identifying Function of an Architectural Dominant in the Structure of a Small Town), 1st ed.; Poznań University of Technology: Poznań, Poland, 2015; p. 202.

60. Ozimek, A. Landscape dominant ELEMENT_An attempt to parametrize the concept. Tech. Trans. 2019, 116, 35-62. [CrossRef]

61. Forczek-Brataniec, U. The Degree of Visibility as a Tool to Assess and Design of a Visual Corridor. In Proceedings of the Fábos Conference on Landscape and Greenway Planning, Budapest, Hungary, 30 June-3 July 2016; Valanszki, I., Jombach, S., Filep-Kovacs, K., Fabos, J.G., Ryan, R., Lindhult, R.M., Kollanyi, L., Eds.; Szent Istvan University: Budapest, Hungary, 2016; Volume 5, pp. $295-302$. 62. Chmielewski, S. Chaos in Motion: Measuring visual pollution with Tangential View Metricks. Land 2020, 9, 515. [CrossRef] 
63. Palmer, J.F. The contribution of a GIS-based landscape assessment model to a scientifically rigorous approach to visual impact assessment. Landsc. Urban Plan. 2019, 189, 80-90. [CrossRef]

64. Rubinowicz, P. Protection of the waterfront panoramas based on computational 3D-analysis. In Architecture in the Age of the 4th Industrial Revolution; eCAADe + SIGraDi: Porto, Portugal, 2019; pp. 325-332.

65. Rubinowicz, P. Application of the Visual Protection Surface Method (VPS) for Protectionof Landscape Interiors within a City. IOP Conf. Ser. Mater. Sci. Eng. 2019, 471, 092048. [CrossRef]

66. Różycka-Czas, R.; Czesak, B.; Cegielska, B. Towards Evaluation of Environmental Spatial Order of Natural Valuable Landscapes in Suburban Areas: Evidence from Poland. Sustainability 2019, 11, 6555. [CrossRef]

67. Zubel, H. Diagram Notation of a Concept in the Process of Architectural Design, Illustrated with the Example of Own Work, with Particular Focus on the Project of Community Centre in Grodzisk Mazowiecki. Available online: Htps://repolis.bg.polsl.pl/ dlibra/publication/70083/edition/61663/content (accessed on 25 December 2020).

68. Hodor, K.; Fekete, A. The sacred in the landscape of the city. Tech. Trans. 2019, 116, 15-22. [CrossRef]

69. Bridgen, T. Value in the "View". In Conserving Historic Urban View; RIBA Publishing: London, UK, 2018.

70. Badach, J.; Raszeja, E. Developing a Framework for the Implementation of Landscape and Greenspace Indicators in Sustainable Urban Planning. Waterfront Landscape Management: Case Studies in Gda' nsk, Pozna 'n and Bristol. Sustainability 2019, 11, 2291. [CrossRef]

71. Bucurescu, I. Managing tourism and cultural heritage in historic towns: Examples from Romania. J. Herit. Tour. 2015, 10, 248-262. [CrossRef]

72. González Santa-Cruz, G.; López-Guzmán, T. Culture, tourism and World Heritage Sites. Tour. Manag. Perspect. 2017, 24, 111-116. [CrossRef]

73. Woźniak, M. Ład przestrzenny jako paradygmat zrównoważonego gospodarowania przestrzenia (en. Spatial order as a paradigm of sustainable space). Białostockie Stud. Prawnicze 2015, 18, 167-182. [CrossRef] 